\title{
Meta
}

Journal des traducteurs

Translators' Journal

\section{Dubuc, Robert (1997): Terminology: A Practical Approach, adapted by Elaine Kennedy, Quebec, Linguatech, 196 p.}

\section{John Humbley}

Volume 44, numéro 2, juin 1999

URI : https://id.erudit.org/iderudit/003153ar

DOI : https://doi.org/10.7202/003153ar

Aller au sommaire du numéro

Éditeur(s)

Les Presses de l'Université de Montréal

ISSN

0026-0452 (imprimé)

1492-1421 (numérique)

Découvrir la revue

Citer ce compte rendu

Humbley, J. (1999). Compte rendu de [Dubuc, Robert (1997): Terminology: A Practical Approach, adapted by Elaine Kennedy, Quebec, Linguatech, 196 p.]

Meta, 44(2), 376-378. https://doi.org/10.7202/003153ar

Ce document est protégé par la loi sur le droit d'auteur. L'utilisation des services d'Érudit (y compris la reproduction) est assujettie à sa politique d'utilisation que vous pouvez consulter en ligne.

https://apropos.erudit.org/fr/usagers/politique-dutilisation/
Cet article est diffusé et préservé par Érudit.

Érudit est un consortium interuniversitaire sans but lucratif composé de l’Université de Montréal, l'Université Laval et l'Université du Québec à Montréal. Il a pour mission la promotion et la valorisation de la recherche. https://www.erudit.org/fr/ 
anglais a colony (swarm) of bees, a pack of dogs, etc. ou a bit (piece, word) of advice, an act of violence, etc.

On a avec le BBI, qui compte, selon les indications données, 18000 entrées et 90000 collocations, une excellente description du fonctionnement de la langue anglaise. L'ouvrage s'avère rapidement indispensable tant pour les enseignants que pour les traducteurs ou pour tous ceux qui ont à écrire. Pour une utilisation optimale, ne pas oublier de lire attentivement l'introduction. Signalons également que les auteurs ont aussi prévu un Cahier d'exercices, un outil précieux pour l'enseignement. On ne peut qu'en recommander l'achat, d'autant plus que le prix est des plus abordables. II n'y a pas à barguigner !

André $\mathrm{Cl}$ as

Université de M ontréal, M ontréal, Canada

\section{RÉFÉRENCES}

Cl as, André (1994) : «Collocations et langues de spécialité», M eta, 39 (4), p. 576-580.

Dar mest et er, Arsène (1887) : La vie des mots étudiés dans leurs significations, Paris, Éditions

Champ Libre, réimpression 1979.

Gr oss, Gaston (1996) : Les expression figées en français, Paris, Ophrys.

Hausmann, Franz Josef (1979) : «Un dictionnaire de collocations est-il possible?», TraLiLi, 17 (1), p. 187-195.

H ausmann, Franz Josef (1991) : «Le dictionnaire de collocations», Wörterbücher, Dictionaries,

Dictionnaires, vol. 3, Berlin, New York, Walter de Gruyter, p. 1010-1019.

Jesper sen, Otto (1924) : La philosophie de la grammaire, Paris, Éditions de M inuit, trad. 1971.

M el'čuk, Igor, André Cl as et Alain Pol guèr e (1995) : Introduction à la lexicologie explicative et combinatoire, coll. «Universités francophones», Louvain-la-Neuve, Paris, Éditions Duculot, AUPELF-UREF.

Sauvageau, Aurélien (1964) : Portrait du vocabulaire français, Paris, Larousse, 286 p.

Du buc, Robert (1997): Terminology: A Practical Approach, adapted by Elaine Kennedy, Quebec, Linguatech, $196 \mathrm{p}$.

Compared with French or German, English does not boast a large number of practical handbooks for terminology. The situation has vastly improved in the 1990's, but a new title is always welcome. So much of current terminology practice was crystallized in Canada in the 1970's and 80's that a publication in English goes a long way towards redressing the balance, heavily weighted towards French up to now.

The new manual is in fact an adaptation of Robert Dubuc's now classical handbook first published in 1978 and currently in its third, greatly reworked and vastly updated edition (1992). Robert Dubuc is a byword on both sides of the Atlantic among a generation of French-speaking students of terminology, who have appreciated a book that lives up to its claim to being practical, a book that gives them the opportunity to launch out into terminology work on their own, without being too much concerned with either the philosophical subtext or the nuts and bolts of current software. Part of the students' enthusiasm stems from the fact that Robert Dubuc had managed to transpose his pedagogical gifts to the written mode and the charisma 
present in his face-to-face teaching jumps off the page. However the importance of this pioneer is less that of an inspired teacher than a major actor in the development of what has come to be known as the Canadian school of terminology. As the creator of the terminology department of Radio Canada, wherequalitéde la langue is no vain word, Dubuc not only conceived one of the first multidomain services, but also set up the guidelines for terminologie ponctuelle or "specific terminology" (dealt with in this book), a real need in any translation unit, but which has been given short shrift by the founding fathers of terminology, who pinned their faith on a conscious construction of conceptual systems, an aspect which is also squarely addressed in this volume.

Whatever the enthusiasm that will inevitably greet the publication of the English version of a great classic, however, there is no way of avoiding the question of its relevance to present-day students of terminology. Is the setting not too specific to the French speakers of N orth America to be transposable to an international audience for whom terminology, as a professional training, may take on many different forms according to the applications envisaged? And, more important still, has terminology not been overtaken by a second information revolution, rendering the textbooks of the first generation, not just technically obsolete, but also too narrow in general orientation? The answer depends largely on what the reader wants out of a textbook, and, depending on the needs, the new English-language Dubuc still has much to offer.

As in the original, many of the strong points are not where they appear to be at first blush. The distinction between lexicology and terminology, brought out very clearly, bordering on the polemical, in earlier editions and retained here, is perhaps indicative of a young discipline struggling for recognition as an academic and professional entity. What remains true for terminology is the firm basis of the engineer's outlook of a problem to be solved, planted firmly in an industrial reality, and this is a constant of all the editions. So is the practical introduction to what special language entails, a fundamental prerequisite of work on terminology and one that is best carried out by means of practical initiation. Earlier editions too demonstrated that formal semantics was not a prerequisite of practical terminology work, and that a workable account of special language can be made with a minimum of linguistics. After all, a linguistic study of special language can be carried out in another context.

Other subtle touches will not go unnoticed. The clear-cut distinction between synonyms and variants is both obvious and workable. The actual form of the term record is not simply presented but worked through with the reader. It may seem too specific; after all, there are many other forms of term record that students may have to use or create in the course of their professional life, and more than one terminologist would today question the relevance of the term record (especially in the singular) for many applications. But this is a practical introduction, and there is no better way of initiating the beginner than through practical work, which implies the choice of examples and a specific choice.

The English version is in fact an excellent adaptation rather than a translation, in which Elaine Kennedy has not simply found English-language examples to substitute for the French, but also recast the whole layout of the book to facilitate access to English-speaking students. The adapter is joined for two important chapters by Catherine A. Bowman, who explains the role of terminology in standardization in the English-speaking context (cogently exposed by Sager in 1990, though from a different 
angle) and gives the principles and the main resources of documentary research, without perhaps conveying the complementary nature of these two sister disciplines. It was to Andy Lauriston that the hardest part of the manual befell, the role of the computer in terminology work, which remains, as in the French editions, the last chapter in the book. Here precedence is given to the terminology tools of translation, which is only natural given the general orientation of the handbook, and also privileges not only English-French translation, but also, less explicably, tools for French terminology extraction. It is to be hoped that future editions will devote more space to the issues of corpus linguistics concerning special languages, and the role of terminology in these endeavors, as this is certainly a major application of terminology in the future.

The adaptation retains the features that have endeared the original to Frenchspeaking students: a host of well chosen, clearly presented examples, a selection of exercises at the end of each chapter, and perhaps most importantly, the supplément d'âme, which, better than any academic demonstration, convinces the beginner that terminology is anything but a dry technical subject, but rather an opening onto whole new worlds.

John Humbley Université Paris 13, Villetaneuse, France

Gent il e, Adolfo, Uldis $\mathrm{O} z o l$ ins and M ary Vasil akakos (with Leong $\mathrm{Ko}$ and TonThat Quynh-Du) (1996): Liaison Interpreting. A Handbook, Melbourne, Melbourne University Press, $144 \mathrm{p}$.

Au commencement était l'interprétation de conférence..., la reine de l'art, la plus prestigieuse, la mieux rémunérée, exercée par les «grands» et, depuis peu, objet de nombreuses recherches et publications. Ne concernant qu'une poignée de praticiens, elle a mal gré tout éclipsé une autre interprétation pratiquée par une armée de professionnels (car, eux aussi, ont une spécialité et en vivent) dans l'ombre des hôpitaux, des tribunaux, des centres de services sociaux, des bureaux de police, etc. : I'interpré tation «de liaison», «communautaire», «en milieu social» ou quel que soit le nom qu'on lui donne dans les différents pays qui l'utilisent largement.

L'ouvrage de Gentile et al. rend enfin à cette profession les honneurs qui lui reviennent. Tous les honneurs, car rien n'est laissé au hasard ni de côté dans ce Manuel qui examine de très près tous les aspects liés à l'interprétation de liaison. Deux parties, l'une générale et l'autre spécialisée, et dix chapitres, six généraux et quatre spécifiques, brossent un tableau complet de tout ce qu'il faut savoir sur cette profession. Le lecteur saura gré aux auteurs de leur clarté, de leur style dépouillé exempt de jargon, mais néanmoins empreint d'une force de conviction au moment de revendiquer, et de leur esprit de synthèse, qui se traduit par un bref résuméà la fin de chaque chapitre.

Le premier chapitre, consacréà un aperçu historique de l'évolution del'interprétation de liaison, est en quelque sorte une définition de celle-ci par rapport à l'interprétation de conférence et à quelques autres activités langagières (guides touristiques, 